\title{
Compartiendo una experiencia: Acerca de los métodos y paradigmas de traducción del Comentario al Evangelio de Juan de Orígenes
}

\author{
Patricia Ciner ${ }^{\circ}$ \\ patriciaciner@yahoo.com.ar \\ Facultad de Filosofía y Letras - Universidad Católica de Cuyo - Argentina \\ Recibido 23.06.2020/ Aprobado 01.08.2020 \\ DOI: $h$ ttps://doi.org/10.46553/teo.57.133.2020.p53-76
}

\section{RESUMEN}

Todos los que nos dedicamos al mundo de la Antiguiedad Tardía en general y a los Estudios Patrísticos en particular, sabemos que las traducciones no son simplemente una transliteración lo más exacta posible, de un vocablo griego o latino a uno castellano. Por el contrario, en toda traducción se esconde un secreto que sólo puede advertirse cuando se tiene la oportunidad de vivir el desafío fascinante y terrible a la vez, de una tarea como ésta. Este desafío consiste en la osadía de dejar hablar a titanes del pensamiento, tales como Ireneo, Orígenes, Agustín, etc. En este artículo sintetizaré los métodos y paradigmas a través de los cuáles, realicé la primera traducción al castellano del Comentario al Evangelio de Juan de Orígenes. Siempre escribiré en primera persona, ya que considero que es mi obligación comprometerme con los criterios que elegí, para permitir que la voz del gran Orígenes se expresara. Los criterios de traducción que explicitaré serán los siguientes: Métodos de investigación, El paradigma de la relacionalidad, El paradigma de la continuidad bíblica-filosófica: la doctrina de las epinoias, la doctrina de la preexistencia, la doctrina de la apocatástasis, la divinización de los seres dotados de Logos.

Palabras clave: Orígenes; Traducción; Comentario al Evangelio de Juan; Métodos; Paradigmas

Sharing an experience: About the methods and paradigms of translation of the Origen's Commentary on the Gospel of John

\footnotetext{
- La autora es investigadora y profesora en la Facultad de Filosofía y Letras de la Universidad Católica de Cuyo y en la facultad de Filosofía, Humanidades y Arte de la Universidad Nacional de San Juan. Es la Presidenta de la Asociación Internacional de Estudios Patrísticos.
} 


\section{ABSTRACT}

All of us who work in the world of Late Antiquity in general and in Patristic Studies in particular know that translations are not simply the most exact possible transliteration of a Greek or Latin word into Spanish. On the contrary, every translation hides a secret that can only be noticed when one has the opportunity to experience the fascinating and terrible challenge of such a task. This challenge consists of the audacity to let the titans of thought speak, such as Irenaeus, Origen, Augustine, etc. In this article, I will summarize the methods and paradigms through which I made the first translation into Spanish of the Commentary on the Gospel of John of Origen. I will always write in the first person, as I consider it my duty to commit myself to the criteria I chose, to allow the voice of the great Origen to be expressed. The criteria for translation that I will make explicit are the following: Research methods, The paradigm of relationality, The paradigm of biblical-philosophical continuity: The doctrine of the epinoias, The doctrine of pre-existence, The doctrine of apocatastasis, The divinization of Logos gifted beings.

Keywords: Origen; Translation; Commentary on the Gospel of John; Methods; Paradigms

\section{A modo de relato autobiográfico}

Todos los que nos dedicamos al mundo de la Antigüedad Tardía en general y a los Estudios Patrísticos en particular, sabemos que las traducciones no son simplemente una transliteración lo más exacta posible, de un vocablo griego o latino a uno castellano. Por el contrario, en toda traducción se esconde un secreto que sólo puede advertirse cuando se tiene la oportunidad de vivir el desafío fascinante y terrible a la vez, de una tarea como ésta. Este desafío consiste en la osadía de dejar hablar a titanes del pensamiento, tales como Ireneo, Orígenes, Agustín, etc. Pero para adentrarse en esa tarea, se requiere según mi experiencia, de dos condiciones básicas: por una parte, de un buen conocimiento de las lenguas clásicas, que permita por ejemplo, que no se pierdan el hyperbatón o los participios del griego, sino que por el contrario, muestren su esencia a través de otros caminos, como los diferentes idiomas modernos. La otra condición, sin duda mucho más importante que la primera, es la humildad indispensable que debe tener un traductor para poder ingresar al recinto sagrado, en donde habita el autor que va a ser traducido. Pero quizás alguien podría preguntarse: ¿Por qué se requiere humildad? La respuesta es simple: porque este recinto es maravilloso 
y también muy peligroso. La maravilla reside en la posibilidad de acercarse a genios de la Patrística, como en mi caso particular a Orígenes, y que sin duda, genera una sensación de poder y de euforia. El peligro por su parte, se oculta en la posibilidad siempre latente de traicionarlos, tanto por ignorancia, como por la soberbia de pensar que uno puede ayudarlos a decir mejor, lo que ellos fueron incapaces de expresar por sus limitaciones temporales. Puedo decir que esta doble sensación de euforia y de terror, me acompañó durante los diez años que duró el trabajo de mi traducción al Comentario del Evangelio de Juan ${ }^{1}$. Y que el único antídoto que encontré para equilibrar mis estados de ánimo, me lo dio Platón, otro gran genio de la Humanidad, a través del inigualable mito de "E $\omega \omega \varsigma^{2}$. En ese sentido, una buena traducción también es hija de "E $\omega \varsigma_{\text {, }}$ en cuánto que el amor tiene la doble condición de riqueza y de pobreza. De riqueza, porque el gran ser al que uno trata de darle una voz en otro idioma que no fue el suyo, lo va guiando con su genialidad; de pobreza, porque los límites de la propia vida humana, se hacen manifiestos cuando se emprende una tarea de la magnitud de una traduccion.

Sólo a modo de anécdota personal, quisiera compartir con ustedes la experiencia de largas y obscuras noches en las que decidía que iba a dejar la traducción, porque excedía mi capacidad y mis fuerzas. Pero también la experiencia de muchas mañanas, en que luego de arrodillarme y pedirle asistencia a mi amado Orígenes, aparecía en mi mente y en mi corazón la forma más exacta de traducir un fragmento complejo, que adquiría entonces sentido, no porque yo se lo diera, sino porque había podido trascender mis límites humanos y la voz del Alejandrino se había expresado. En síntesis: la traducción de los grandes autores de la Patrística, requiere de una inmensa humildad y al mismo tiempo de una inmensa osadía para abrir las puertas de la Eternidad, permitiendo

1 Orígenes, Comentario al Evangelio de Juan/1, Prólogo, F. García Bazán, Introducción, traducción y notas, Patricia, A. Ciner, Biblioteca de Patrística N N $^{\circ} 15$ (Madrid:Ciudad Nueva 2020; Orígenes, Comentario al Evangelio de Juan/2, Introducción, traducción y notas, Patricia, A. Ciner, Biblioteca de Patrística N 116 (Madrid: Ciudad Nueva, 2020).

2 Platón, Symp. 203 bc. 
así el acceso, a todos aquellos que anhelan tener el contacto con estos gigantes del pensamiento.

A continuación, sintetizaré los métodos y paradigmas a través de los cuáles realicé la traducción, de esta obra maestra del Alejandrino. Siempre escribiré en primera persona, ya que considero que es mi obligación comprometerme con los criterios que elegí, para permitir que la voz del gran Orígenes se expresara. También por supuesto, estaré sumamente agradecida con los colegas que enriquezcan mi perspectiva de interpretación, ya que estoy convencida de que la colaboración entre académicos, siempre permite reconstruir con más exactitud, el legado de los grandes autores patrísticos

\section{Métodos de investigación}

En la actualidad, los Estudios Patrísticos abordan los diversos problemas que se suscitaron en este período apasionante de la historia de Occidente, desde una doble perspectiva: por un lado, se estudian las escuelas y los pensadores cristianos en relación con las diversas escuelas de la época y en este sentido se prefiere hacer referencia a la categoría histórica de Antigüedad Tardía ${ }^{3}$ como marco de comprensión en el que deben cotejarse las diversas teorías y doctrinas de los autores patrísticos y al mismo tiempo se los aborda desde la especificidad de la Patrística. Esto no significa por cierto, que los autores cristianos pierdan su identidad, sino simplemente implica enmarcarlos dentro del contexto en el que los mismos autores realizaron siempre sus análisis. Así entonces, no puede perderse de vista que, por ejemplo tanto los padres de la Iglesia como los gnósticos, eran hombres de su tiempo, y conocían perfectamente las coordenadas culturales, políticas y por supuesto también, las coordenadas filosóficas y teológicas de su época ${ }^{4}$. En ese sentido, el

3 Cf. P. Hadot, Ejercicios espirituales y filosofía antigua (Madrid: Siruela, 2006), P. Brown, El Mundo en la Antigüedad Tardia (Madrid: Gredos, 1991).

4 Cf. B. Bitton-Ashkelony, T. De Bruyn, C. Harrison (ed.), Patristic Studies in the Twenty-First Century, (Turnhout: Brepols, 2015). Este libro es el resultado del encuentro realizado en Je- 
método de investigación que utilicé en la traducción fue triple, ya que permanentemente combiné la generalidad del «macrocontexto» que proporciona la categoría histórica de la Antigüedad Tardía, con la especificidad del «microcontexto» que otorgan los estudios patrísticos y la singularidad que implica la teología de Orígenes.

Es necesario señalar además, que la especificidad del cristianismo es a su vez múltiple, ya que la existencia de una diversidad de corrientes en el cristianismo primitivo, parece ser un hecho indiscutible para la investigación contemporánea. En tal sentido, citaré la reflexión realizada por G. Luttikhuizen en su libro La pluriformidad del cristianismo primitivo:

«El descubrimiento en el siglo pasado de fuentes judías y cristianas, hasta entonces desconocidas, en especial los escritos de Qumrán y la biblioteca de Nag Hammadi, propició una profunda revisión de la concepción tradicional del judaísmo antiguo, del cristianismo primitivo y en general, del mundo religioso de la Antiguiedad Tardía. En lo que al cristianismo se refiere, dichas fuentes nos ofrecen una visión totalmente nueva del cristianismo primitivo y de la gran diversidad que debió caracterizar sus primeros siglos de existencia» ${ }^{5}$.

Esta última reflexión permite advertir con meridiana claridad, que la pluriformidad en el cristianismo primitivo, surgió evidentemente a partir de la diversidad de interpretaciones de acontecimientos y nociones teológicas. Ésa será justamente la clave para comprender desde una visión contemporánea, que Orígenes fue básicamente un teólogo comprometido, que tuvo en muchos aspectos una perspectiva diferente, pero no por eso equivocada o herética del advenimiento de Cristo a la historia de la humanidad. En ese

rusalén, con ocasión de cumplirse el 50 aniversario, de la Asociación Internacional de Estudios Patrísticos (AIEP). En los diversos capítulos en que está estructurado este texto, es posible constatar cómo la mirada en que se sustentan los estudios patrísticos en la actualidad es básicamente interdisciplinaria. Esto significa que, si bien la Teología Patrística continúa cumpliendo un papel fundamental, no se puede considerar un único camino de acceso a los diversos problemas de la época. En efecto, otras disciplinas tales como, la Filosofía, la Historia, el Arte, la Arqueología, la Sociología, la Pedagogía, etc., colaboran también para una mejor comprensión de este período fascinante de la humanidad.

5 G. P. Luttikhuizen, La pluriformidad del cristianismo primitivo, (Córdoba: El Almendro, 2002), 13. 
sentido considero que, la clasificación de los diversos cristianismos en «protoortodoxos o protocatólicos, judeocristianos y gnósticos»${ }^{6}$ que los especialistas contemporáneos han realizado, debe ser ampliada aún más, ya que la teología de Orígenes, si bien se encuentra más cerca de lo que ha dado en llamarse protoortodoxia, tiene características únicas y distintivas con respecto a otros autores que se ubican en esta tradición. Han sido esas características únicas, las que fueron tan mal comprendidas por la posteridad y que terminaron produciendo las condenas del Concilio de Constantinopla en el año 5537. Por esta razón, estoy convencida que el Clo de Orígenes, que puede ser considerado tal como afirmó H. Crouzel, «la obra maestra» ${ }^{8}$ del alejandrino, requiere de un nuevo abordaje para ser leída y comprendida en profundidad.

\section{El Paradigma de 1a Relacionalidad}

Otro de los grandes desafíos a la hora de traducir un texto como el Clo es identificar el paradigma desde donde el alejandrino piensa, escribe y vive, ya que sin duda la falta de claridad al respecto, ha generado incomprensiones hacia su obra. Pienso que la comprensión de este paradigma, al cual denominé de la «relacionalidad», permite contextualizar tanto las doctrinas condenadas, como así también la majestuosidad de todo su sistema. Desde mi perspectiva, el fundamento de este paradigma en el Clo se encuentra en el supuesto de la presencia de Dios Padre y de su Hijo, que se manifiestan en todos los planos de la existencia a través de las ė̃ívolaı más antiguas del Hijo: la Sabiduría y el Logos. Ambas

6 Cf. F. García Bazán, La Biblioteca gnóstica de Nag Hammadi y los orígenes cristianos, (Buenos Aires: El Hilo de Ariadna, 2013), p. 39. Sobre este tema también, cf. D. Brakke, Los Gnósticos. Mitos, ritual y diversidad en el cristianismo primitivo (Salamanca: Ed. Sígueme, 2013); L. Hurtado, Señor Jesucristo. La devoción a Jesús en el Cristianismo Primitivo (Salamanca: Sígueme 2008).

7 Cf. A. Guillaumont, Les 'Kephalaia Gnostica' d'Evagre le Pontique. Et l'histoire de l'origénisme chez les grecs et chez les syriens (Paris, Éditions du Seuil, 1962)

$8 \mathrm{Cf}$. H. Crouzel, Orígenes. Un teólogo controvertido (Madrid: BAC, 1999), 65. 
Ėđívoı $\alpha \imath^{9}$ sintetizan la esencia misma del Hijo, pero no como entidades diferentes, sino como momentos ontológicos. En ese sentido, Orígenes era plenamente consciente de que de su definición de Sabiduría, dependía de su cercanía o lejanía de la filosofía griega y helenística, de toda la literatura sapiencial hebrea y muy especialmente del pensamiento gnóstico ${ }^{10}$. Esto se ve claramente expuesto en este fragmento del Libro I del Clo:

«La Sabiduría dice, en efecto, en Salomón: «El Señor me ha formado como el principio de sus caminos en vista de sus obras", de manera que el Logos existía en el principio, [es decir] en la Sabiduría: pues la sabiduría es considerada en la formación del pensamiento que ha organizado todas las cosas y en la de sus nociones y el Logos en la comunicación de las consideraciones de este pensamiento a los seres dotados de logos... Mira si nosotros no podemos interpretar el texto: «En el principio existía el Logos", según el sentido espiritual: todas las cosas son creadas según la sabiduría de acuerdo a líneas directrices de un plan cuyas nociones están en el Logos» ${ }^{11}$.

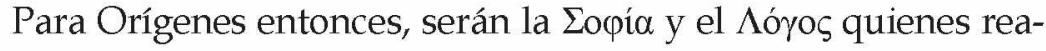
licen el puente de comunicabilidad ${ }^{12}$ y de relacionalidad entre todas las dimensiones de lo real y serán también los dos hilos invisibles que organicen los temas de esta obra. Y por tal razón, deberá considerarse a Orígenes como un pensador sistemático. Soy consciente de que esta última afirmación, tiene consecuencias a la hora de precisar los límites y alcances de su llamada teología gimnástica o teología en búsqueda ${ }^{13}$. Esta forma de pensar y de escribir tiene por cierto, un lugar relevante en el pensamiento de Orígenes, ya que es el sello

9 La noción de k̇ंívol $\alpha$ es central para comprender la teología de Orígenes. Básicamente hace alusión a las denominaciones que el Hijo adopta. Orígenes examinará en detalle cuáles son esenciales al Hijo y cuáles ha adoptado en relación con la caída de las criaturas intelectuales y la consecuente necesidad de su encarnación, a fin de ayudarlas en el camino hacia la apocatástasis. Sobre este tema pueden consultarse la siguiente bibliografía: H. Crouzel, Origen et Plotin. Comparaisons doctrinales ( Paris: Pierre Téqui,, 1991), pp. 145-154; J. Wolinski, «Le recours aus Ėंívora du Christ dans le Commentaire sur Jean d' Origene», en Origeniana Sexta, en G. Dorival/ A. Le Boullec (eds.) ( Louvain: Peeters, 1995), 466-492.

10 P. Ciner, Implicancias Teológicas y Místicas de la noción de Sabiduría en Orígenes (Mendoza: Publicación del Centro de Estudios de Filosofía y Letras, 2010 ), Año III, Nº 6.

$11 \mathrm{Clol}, 111-113$.

12 Cf. J. Rius Camps, "Comunicabilidad de la Naturaleza de Dios según Orígenes» (Roma: Orientalia Christiana Periodica, 1968), pp. 1-35.

13 Cf. L. Perrone, «Método», en Adele Castagno (director), Diccionario de Origenes (Burgos: Monte Carmelo, 2003) pp. 567-575; H. Crouzel, Orígenes Un teólogo controvertido..., 229-237. 
distintivo que lo ha caracterizado como un teólogo libre y valiente. Sin embargo, esta actitud de honestidad intelectual para expresar sus dudas ante temas muy complejos, no se opone a la existencia de este núcleo sistemático, firme y preciso, que se encuentra en todos sus escritos. Como consecuencia de esto, las aparentes tensiones y contradicciones en el estudio de algunos problemas teológicos-filosóficos, se resuelven y se comprenden desde la concepción de la relacionalidad que vincula el cosmos inteligible con el sensible, la eternidad con el tiempo. Esto, por supuesto, tiene un claro sentido antignóstico, ya que busca erradicar todo tipo de caída pleromática y con ello cualquier vestigio de acosmismo y de dualismo. Pero si bien este paradigma de la relacionalidad resulta muy claro a la hora de analizar la cosmología origeniana, algún lector avezado podría preguntarse, si es posible aplicarlo a su antropología. Decimos esto en función de que, con frecuencia, se encuentran en el Clo, textos del tenor siguiente:

«En Isaías, Él dice que el Padre «ha hecho de su boca una espada de acero» y que lo ha escondido en la palma de su mano, que lo ha hecho semejante a una flecha elegida y lo ha escondido en la aljaba del Padre. El Padre lo llama servidor del Dios del Universo, Israel y luz de las naciones ${ }^{14}$. La boca del Hijo de Dios es una espada acerada, porque la palabra de Dios está viva, es eficaz, más afilada que una espada con dos filos, ya que ella penetra hasta la división del alma y del espíritu, de las coyunturas y de las médulas, y juzga los sentimientos y los pensamientos del corazón ${ }^{15}$. Sobre todo, porque Él no vino a traer paz sobre la tierra (esto es, a los seres corporales y sensibles), sino la espada ${ }^{16}$, cortando, si se puede decir así, la amistad perjudicial del alma y del cuerpo, para que el alma entregándose al espíritu que combate contra la carne ${ }^{17}$, se haga amiga de Dios, que tiene por boca según la palabra del profeta, una espada o como una espada acerada. Viendo tantos hombres heridos por el amor divino, así como la esposa que en el Cantar de los Cantares confiesa en estos términos haber experimentado estar herida: yo estoy herida de amor ${ }^{18}$, se encontrará que la flecha que ha herido a tantas almas con el amor de Dios, no es otra más que esta que ha declarado: Él ha hecho de mí una flecha elegida» ${ }^{19}$.

14 is $49,2.3 .6$.

$15 \mathrm{Cf} . \mathrm{Hb} 4,12$.

16 Cf. Mt 10, 34.

17 Cf. Ga $5,17$.

$18 \mathrm{Ct} 2,5$.

19 Clo II, XXXII. 228. 
Las preguntas que inmediatamente surgen son las siguientes: ¿se evidencia en este texto un claro dualismo antropológico? o, por el contrario, ¿es posible encontrar en el pensamiento de Orígenes algún tipo de vínculo o relación entre las dimensiones de la materia y el espíritu, entre el tiempo y la eternidad? Al respecto, diremos que Orígenes es muy claro al afirmar que la materia no es mala en sí misma, y así lo ha sostenido en textos como éste:

\begin{abstract}
«Ahora bien, que el mal no venga de Dios, es cosa cierta. También, según nuestro Jeremías, es claro que de la boca del Señor no saldrán los males y el bien, pero que la materia que habita entre lo mortal tenga la culpa del mal, no es, según nosotros, verdad. La verdad es que la culpa de la maldad que hay en cada uno la tiene su propia voluntad, y esa maldad es el mal, y males son también las acciones que proceden de ella. $Y$, hablando con rigor, según nosotros, ningún otro mal existe ${ }^{20}$.
\end{abstract}

Vemos pues que la materia, no se opone esencialmente al espíritu, sino que también forma parte de la obra de Dios. Para Orígenes es la intención de la voluntad humana, la que genera la aparición del mal al intentar separarse del plan divino y hacer mal uso del don del libre albedrío. La clave de la medida en el buen o en el mal uso del libre albedrío, estará dada para Orígenes en la expre-

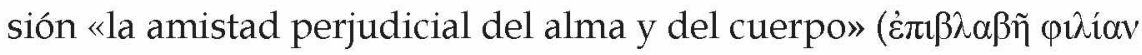

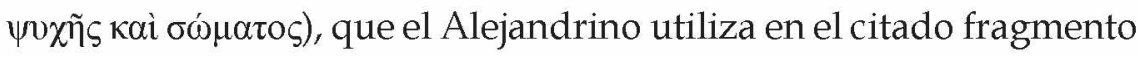
del Clo. Esta amistad sólo será perniciosa cuando la materia no se relacione correctamente con el espíritu, o dicho en otros términos, cuando el tiempo no se subordine a la eternidad. Cuando esto suceda las almas perderán de vista su destino final, que es retornar de manera plenificada a su calidad de voćs, en la apocatástasis. Por esta razón, Orígenes será muy cuidadoso a la hora de definir los términos alma y espíritu, pues, si bien estarán esencialmente relacionados, constituirán dimensiones diferentes. Por esta razón y siendo plenamente consciente de que sus investigaciones, pueden causar 
algún malestar entre los cristianos no acostumbrados a la reflexión profunda y libre sobre estos problemas, afirma que:

«Me he atrevido a investigar en estos temas, pero con discreción, debido a que he notado en toda la Escritura una diferencia entre el alma y el espíritu. Yo he observado en efecto, que el alma es algo intermedio, capaz de virtud y de vicio, mientras que el espíritu del hombre que está en él ${ }^{21}$, no admite nada inferior, pues los más excelsos bienes son llamados frutos del espíritu ${ }^{22}$ y no como alguno podría pensar [frutos] del Espíritu Santo, sino del espíritu del hombre» ${ }^{23}$.

Esta definición, respecto a la diferencia entre alma y espíritu, es ciertamente muy clara, ya que permite comprender aspectos fundamentales de la antropología origeniana. Así, por ejemplo, los siguientes: el alma encarnada en el tiempo ( $\dot{\eta} \psi \wedge \chi \chi \dot{)}$ es básicamente la sede del libre albedrío y por tanto capaz de virtud y de vicio, y al mismo tiempo el espíritu divino que habita en el alma, jamás puede obscurecerse con el vicio. En otros términos, la caída de los voés en la preexistencia, a causa del uso de su libre arbitrio, no produce una real desconexión ni con la eternidad ni con la divinidad. En ese sentido, la dimensión del espíritu jamás se une substancialmente al compuesto psicofísico. Sin embargo, esto no implica un dualismo irreductible, ya que en toda alma coexisten dos niveles, el superior y el inferior, que si se relacionan correctamente, es decir jerárquicamente, otorgan paz y armonía. Esto por supuesto, requiere de un esfuerzo permanente y de la práctica del camino al que Orígenes denomina «progreso espiritual». A través del progreso, que incluye el esfuerzo humano y la gracia divina, el alma recupera y descubre la presencia de la eternidad del principio, que vive y da sentido al tiempo. Por esta razón, el alma humana será el lugar privilegiado del encuentro entre eternidad y tiempo. Este encuentro se producirá a partir de la activación del nivel superior, que permite contemplar la presencia de lo divino en el alma y con ello recuperar su 
divinidad esencial como vó ç, que no es destruida por la caída en la encarnación. Este nivel es llamado por Orígenes de diversos modos, según el contexto de explicación que esté dando, evidenciando de esta forma claridad y precisión en el vocabulario a la hora de distinguir las diversas tradiciones filosóficas y teológicas. Así, a veces lo denominará con un término platónico, voũc, o con uno estoico como

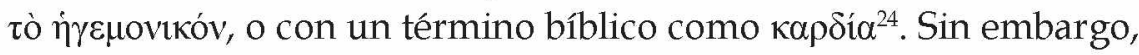
estos términos no son absolutamente sinónimos y requieren de una cuidadosa distinción, por parte del lector avezado en Orígenes ${ }^{25}$. A partir de todo lo expuesto, pienso que también es posible concluir que este paradigma de la relacionalidad, subyace a la antropología del Alejandrino.

\section{El paradigma de la continuidad bíblica-filosófica}

Algunos especialistas han sostenido que, como consecuencia de los problemas que Orígenes tuvo en Alejandría o a causa quizás de una decisión personal, el Alejandrino modificó su estilo especulativo, centrándose en Cesarea en uno más bíblico y catequético. Así por ejemplo R. Heine ha afirmado que:

«He hecho un serio intento en este libro para tratar por separado las obras de Orígenes en Alejandría y sus obras en Cesarea, sin arrojar su contenido en un solo recipiente y agitarlas para dar una visión homogeneizada de su pensamiento. Esta separación también distingue, por consiguiente, entre el pensamiento del joven y del anciano Orígenes. Ninguna de estas distinciones ha sido tomada muy en serio en los estudios de Orígenes... El argumento de este libro es que las nuevas situaciones trajeron nuevos pro-

24 Cf. H. Crouzel, Orígenes. Un teólogo controvertido..., pp. 125-132. El especialista francés afirma que: «el elemento superior es llamado ya sea con un término platónico, el nous o la mens, al que nosotros Ilamaremos «inteligencia, para evitar nombrarlo "espíritu»; ya sea con un término estoico el hégemonikon, traducido en latín por principale cordis o mentis o animae, «la facultad hegemónica» o «principal», ya sea con un término bíblico, kardía o corazón, el «corazón». El elemento inferior recibe varios nombres que iremos viendo».

25 Cf. P. Ciner, «Presencia de la Teología del Corazón en el pensamiento de Orígenes», en Estudios Patrísticos (Villa María:Ediciones del IAPCH, 2004), 21-44. En este artículo se afirma que: «La conclusión que se obtiene de este análisis, nos lleva a sostener que si bien Orígenes utiliza en muchas ocasiones un vocabulario filosófico de tradición helenística, para referirse a las realidades antropológicas más elevadas, a la hora de señalar el lugar donde se produce la comunicación con lo divino, elige el corazón como ámbito sagrado». 
blemas a Orígenes, y estos nuevos problemas le hicieron dirigir su atención en nuevas direcciones, $y$ a veces, incluso a repensar posiciones antiguas» ${ }^{26}$.

Mi perspectiva con respecto a esta cuestión será diferente, ya que considero que este análisis, que quizás pueda aplicarse a otros textos, no es válido para el estudio del $\mathrm{Clo}$, debido a que existe en esta obra una continuidad temática desde el primero al último libro. Esa continuidad a la que he denominado bíblico-filosófica se ve reflejada en las siguientes doctrinas que reaparecen a lo largo de esta obra maestra: las epinoias, la preexistencia, la apocatástasis y la divinización de los seres dotados de Logos. Intentaré probar esta última aseveración, comparando fragmentos del Libro I con fragmentos del Libro XXXII. De esta forma, será posible identificar la similitud de vocabulario y de contenido utilizado por Orígenes en ambos libros. Este rastreo, por supuesto, podría hacerse a lo largo de los nueve libros del Clo, pero en esta ocasión me circunscribiré al primero y al último, como una forma de probar la continuidad de líneas doctrinales. También señalaré que si bien en el Libro XXXII hay un mayor énfasis de la doctrina de la gracia con respecto a los libros escritos en Alejandría, esto no significa un cambio de orientación en los supuestos básicos de la doctrina origeniana, sino una mayor profundización en la distinción entre la tradición cristiana y griega, que Orígenes siempre tuvo clara desde el período alejandrino. En este apartado expondré entonces, la continuidad de los temas anteriormente mencionados.

\section{4.a. La doctrina de las epinoias}

A. Orbe ha afirmado que «la teoría verdadera de las epinoias eclesiásticas hace su aparición en Orígenes, y constituye una de las

26 R. Heine, Origen Scholarship in the Service of the Church (New York: Oxford University Press, 2010), prefacio (la traducción es nuestra). 
claves de su Cristología ${ }^{27}$. En efecto, el lenguaje de Orígenes ofrece distintas expresiones para nombrar al Hijo ${ }^{28}$. Los libros I y II se centran en el análisis de las denominaciones o aspectos (Ėzívora1) de Cristo como Sabiduría, Logos, Verdad, Justicia, Redención, etc., que se encuentran tanto en el Antiguo como en el Nuevo Testamento. Evidentemente las dos غ̇ंívoı $\alpha ı$ más importantes para comprender

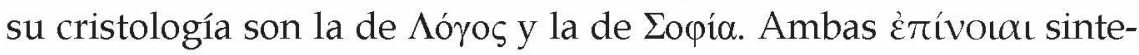
tizan la esencia misma del Hijo, pero no como entidades diferentes, sino como momentos ontológicos del Hijo. La función del Logos es esencialmente la de mensajero y en ese sentido revela a todas las criaturas, los misterios contenidos en la Sabiduría. A fin de mostrar la continuidad de esta doctrina, he seleccionado dos fragmentos, pertenecientes respectivamente al Libro I y al Libro XXXII. En el Libro I, Orígenes escribe:

\begin{abstract}
«Una vez reunidos los nombres del Hijo, se debe verificar cuáles le vinieron después, pues si los santos hubieran permanecido en la beatitud primera, Él no se habría convertido en tantas cosas. Posiblemente no quedaría más que la «Sabiduría», sin duda también el «Logos» y la «Vida», y seguramente la «Verdad», pero ninguno de los otros [nombres] que Él ha tomado por nuestra causa. $»^{29}$.
\end{abstract}

En el Libro XXXII afirma por su parte que: «Ahora bien, buscar a Jesús es buscar al Logos, a la sabiduría, a la justicia, a la verdad y a la potencia de Dios, todas las cosas que es Cristo» ${ }^{30}$.

Puedo concluir este apartado afirmando que, esta doctrina es un ejemplo claro de lo que he denominado el paradigma bíblico-filosófico de Orígenes, que consiste en el delicado equilibrio con que el alejandrino consideraba los contenidos bíblicos, a la luz de los conocimientos provenientes de la filosofía.

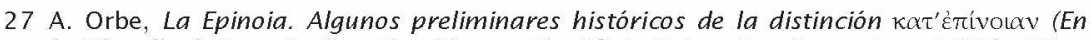
torno a la Filosofía de Leoncio Bizantino (Roame: Pontificia Universitas Gregoriana, 1955), 17

28 «ijo», en Diccionario de Origenes, por Domenico PAZzIN en Diccionario de Origenes..., 425.

29 Clo I, XX, 123.

30 Clo XXXII, XXXI, 387. La misma afirmación se encuentra también en el Libro XIX del Clo (XII, 7). 


\section{4.b. La doctrina de la preexistencia: breves consideraciones}

En investigaciones anteriores ${ }^{31}$ he sostenido, que la doctrina de la preexistencia, no es como lo sostuvo H. Crouzel «la hipótesis favorita de Orígenes y al mismo tiempo la más extraña de su teología» ${ }^{32}$. Por el contrario, he afirmado que es un pilar fundamental de su doctrina, sin la cual toda la belleza y profundidad de sus posteriores desarrollos se derrumban por completo. Por tal razón, he intentado también clarificar y resignificar la palabra preexistencia (en latín praexistentia ${ }^{33}$. Es indispensable destacar al respecto que, el verbo utilizado en el texto de las condenas del Concilio de Constantinopla fue $\pi \rho 0 \ddot{\pi} \pi \alpha \chi \omega^{34}$, que es también el verbo que Orígenes utiliza en el Clo (II, XVIII, 129) para referirse al Logos que está desde el principio en el alma. Este verbo está formado por las preposiciones

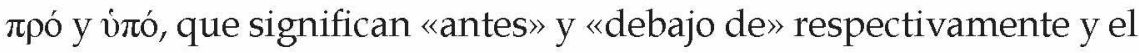
verbo å $\rho \chi \omega$, que entre sus múltiples significaciones puede ser traducido como «dar origen», «comenzar», «preceder», «ser la causa de», etc. Si se unen todos los matices de este complejo y hermoso verbo y se los aplica a la obra de Orígenes, en donde lo que «da origen» hace alusión a la sabiduría eterna de Dios y de su Hijo, debería ser entendido «como la eternidad del principio que está antes del tiempo y subyace en él». Por esta razón, considero que la clarificación del término preexistencia permitirá comprender el objetivo del maestro Alejandrino, que está dirigido a mostrar la continuidad de la eternidad en el tiempo, y cómo esta eternidad del principio convive con la dimensión material que está sujeta al tiempo y al espacio. En

31 Cf. P. Ciner, «Una relectura del De Principiis a la luz del Comentario al Evangelio de Juan. La cuestión de la preexistencia», en Teología y Vida, LV (2014), 263-285.

32 Cf. Henri Crouzel, Origenes. Un teólogo controvertido, 289.

33 Es muy importante destacar que, Rufino utiliza en Prin II, 10,7(20) y en III,6,1(19)), las expresiones «prima conditionis» $y$ « prima conditione» respectivamente, que han sido traducidas por S. Fernández «como primera creación», para referirse a la doctrina de la preexistencia. Posiblemente y sólo a modo de conjetura, se podría afirmar que la expresión «doctrina de la preexistencia», comenzó a utilizarse con posterioridad a las condenas del Concilio de Constantinopla.

34 Cf. J. D. Mansi, Sacrorum conciliorum nova et amplissima collectio, tomus nonus (Graz: Akademische Druck- U. Verlagsanstalt (ADEVA), 1960), 533-534; J. P. Migne, PL (Patrologiae Cursus Completus, Tomus LXIX), Justiniani Lib. Adv. Origenem, p. 221 ; H. Denzinger, P. Hünermann, El Magisterio de la Iglesia (Barcelona: Herder, 2000) 408-409. 
otros términos: que las criaturas intelectuales $\left(\right.$ Voćs $\left.\varsigma^{35}\right)$ jamás pierden la herencia espiritual proporcionada por Dios a través de la imagen inscripta en ellas. Esta imagen les otorga la capacidad de acaecer y asemejarse a Dios a través del progreso espiritual. En efecto, en el Libro I Orígenes escribe que:

«Es necesario preguntarse, si mientras que los santos llevaban en la beatitud una vida totalmente inmaterial e incorpórea, el que recibe el nombre de dragón no merece ser el primero en estar vinculado a la materia y a un cuerpo, ya que él cayó de la vida pura» ${ }^{36}$.

Y en el Libro XXXII afirma en total consonancia con este fragmento que:

«En efecto, habiendo sido muchos los príncipes, uno solo ha caído y es como él y a imitación de su caída, como caen los pecadores. Porque así como aquel [príncipe] que estaba en la divinidad ha caído, así también aquellos a los que el Logos dice, yo he dicho: vosotros dioses sois e hijos del Altísimo, todos vosotros, luego de haber caído de la beatitud y a pesar de que ellos no eran originariamente hombres, mueren como hombres y caen como uno de los príncipes»" ${ }^{\prime 37}$.

Si se comparan estos fragmentos, es evidente el uso de los mismos términos. Los más significativos son sin duda los siguientes:

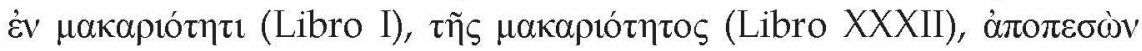
(Libro I), ஷ่ tos, el alejandrino sostiene la existencia de una condición originaria, previa a la transformación en ángeles, seres humanos o demonios, a la que denomina beatitud ( $\tau \tilde{\eta} \varsigma \mu \alpha \kappa a \rho t o ́ \tau \eta \tau ం \varsigma){ }^{38}$. Considero entonces, que estos fragmentos, muestran claramente que la doctrina de la preexistencia, no es una hipótesis, sino un supuesto fundamental del sistema del Alejandrino, que ha mantenido a lo largo de toda

35 Cf. H. Crouzel, Origenes. Un teólogo controvertido...289. El especialista francés realiza una interesante acotación: «Nunca hemos encontrado en las obras griegas de Orígenes el término voũs en plural. Como él declina este término según la declinación ática y no la de la koiné, salvo cuando cita el Nuevo Testamento, habría dicho ciertamente en plural, vol y nunca voés».

36 Clo I, XVII 0,97 .

37 Clo XXXII,XVIII,233-234

$38 \mathrm{Cf}$. B. Blosser, Become like the angels. Origen's Doctrine of the Soul (Washington: Catholic University of America Press, 2012). 
su vida. En ese sentido, pienso que las condenas del Concilio de Constantinopla ${ }^{39}$ a la doctrina de la preexistencia se hicieron desde un paradigma teológico y filosófico que impidió comprender la relación existente entre tiempo y eternidad, entre principio y fin, entre gracia y libre albedrío.

\section{4.c. La doctrina de la apocatástasis}

La doctrina origeniana sobre un estado preexistente de todas las inteligencias, en el que tuvo lugar un proceso de diversificación a raíz de la decisión voluntaria de las mismas de disminuir el amor hacia lo divino, tiene su correlato en la doctrina de un retorno universal y salvífico de todos y cada uno de los seres, en la unidad. Con claridad y contundencia, Emanuela Prinzivalli, ha afirmado que: «en todo el arco de tiempo y en todos los géneros literarios de la producción origeniana se encuentra confirmación de esta doctrina $»^{40}$. Esto tendrá lugar en un momento bien determinado, al término de una sucesión ininterrumpida de siglos o mundos, en el momento del fin último, según lo expresado por Pablo en 1 Co 15, 23-28. La interpretación de este último texto, constituye sin duda, la base de la noción de apocatástasis origeniana. I. Ramelli ha señalado también, que la tensión existente entre la providencia divina y la libertad de las criaturas, alcanza para Orígenes su reconciliación en la apocatástasis. En ese sentido, Orígenes siempre sostendrá la sinergia entre la gracia divina y la libertad humana. Así en efecto, lo explica el Alejandrino, al afirmar en el Libro I que:

«Yo pienso que este camino tiene su final en lo que se llama la "apocatástasis", porque no quedará entonces ningún enemigo más, si estas palabras

$39 \mathrm{Cf}$. A. Guillaumont, Les 'Kephalaia Gnostica' d'Evagre le Pontique. Et l'histoire de l'origénisme chez les grecs et chez les syriens... 140-147.

40 E. Prinzivalli, «Apocatástasis», en A. Castagno (dir.), en Diccionario de Orígenes...,80-89. Cf. I. Ramelli, The Christian Doctrine of Apokatastasis. A critical Assessment from the New Testament to Eriugena, (Leiden-Boston: Brill, 2013). 
son verdaderas: Es necesario que Él reine hasta que haya puesto todos sus enemigos bajo sus pies, el último enemigo que será aniquilado, será la muerte»" ${ }^{41}$.

En clara continuidad con este fragmento, escribe en el último libro del Clo:

«Nosotros sin embargo decimos, en el sentido más simple, que quizás Jesús antes de descender a lo que se llama "el corazón de la tierra", ha restablecido (ả $\varepsilon \kappa \alpha \tau \varepsilon \dot{\sigma \tau \eta \sigma \varepsilon v) ~ e n ~ e l ~ p a r a i ́ s o ~ d e ~ D i o s ~ a l ~ h o m b r e ~ a ~ q u i e n ~ h a b i ́ a ~ d i c h o: ~}$ Acuérdate de mí cuando estés en tu reino... $\gg^{42}$.

Estos bellos textos del CIo, permiten comprender que el objetivo fundamental del Alejandrino al postular su doctrina de la restauración final, es la demostración del amor divino, como único motor de la historia de la salvación.

\section{4.d. La divinización de los seres dotados de Logos}

Uno de los aspectos más sobresalientes en la teología de Orígenes es sin duda alguna, el énfasis en el papel del progreso espiritual $^{43}$, como camino para la divinización plena de las criaturas intelectuales. La clave hermenéutica para comprender este proceso, que se extiende desde la preexistencia hasta la apocatástasis, reside

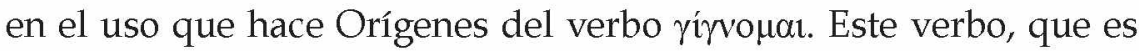
uno de los más utilizados en el Clo, hace referencia al proceso dinámico para llegar a ser hijos de Dios y debe por lo tanto ser traducido, como «llegar a ser»o «devenir» ${ }^{44}$. Orígenes enseña a través de su uso, que la divinidad esencial de las criaturas intelectuales debe ser desenvuelta y perfeccionada. En ese sentido, uno de los gran-

41 Clo I, XVI, 91.

42 Clo XXXII, XXXII, 396

43 La categoría de progreso espiritual ( $\pi$ poколí) es esencial en la mística origeniana. Esta categoría es universal y permite que todos los seres, independientemente del grado de alejamiento de Dios, puedan regresar gradualmente a lo divino. Cf. «Perfecto» por P. Bettiolo, 724-728 y «Progreso» por G. Lettieri, en A. Castagno (director) en Diccionario de Orígenes, Burgos 2003.

44 Cf. P. Ciner, «Devenir hijo de Abrahán: exégesis y mística en el Comentario al Evangelio de Juan de Orígenes», en J. C. Caamaño y H. Giudice (eds.), Patrística, Biblia y Teología. Caminos de diálogo (Buenos Aires: Agape, 2017), 73-81. 
des méritos del alejandrino, ha sido distinguir entre las nociones de libre albedrío como don otorgado por Dios en la preexistencia $y$ el estado de libertad total ${ }^{45}$, alcanzado a través del progreso espiritual, aún después de la muerte física ${ }^{46}$. Hago esta última aclaración en función de la nítida posición de Orígenes en Prin II, 11, 7, con respecto a la posibilidad de progreso y aprendizaje post mortem. También esta doctrina está esbozada en el Clo, aunque en esta obra el maestro Alejandrino profundiza en la posibilidad de perfeccionamiento de los seres humanos o usando su terminología, en los seres dotados de $\operatorname{Logos}^{47}$. La consumación de este progreso en este «mundo variado y diverso ${ }^{48}$ está sintetizada en la categoría de los perfectos (oi $\tau \dot{c} \lambda \varepsilon ı \imath$ ).

En la teología origeniana del Clo está categoría está referida a aquellos seres que han alcanzado durante la vida física, el mayor grado de semejanza con el Hijo y cuyo único alimento es la Sabiduría misma ${ }^{49}$. Esto no implica que este estado esté reservado a unos pocos, ya que el núcleo primordial de Orígenes es postular la posibilidad de salvación universal. Por tal razón, las formas de partici-

45 Cf. L. Pons, El problema de la libertad en Orígenes (Buenos Aires: Agape 2019).

46 Prin II. 11.7: «Algo así hay que decir también sobre el lugar del aire. En efecto creo que todos los santos, al partir de esta vida, permanecerán en algún lugar de la tierra, al que la Escritura divina llama 'Paraíso', como en un lugar de instrucción y, como si dijera, en una sala de audiencia, o escuela de almas, en que serán adoctrinados en todo aquello, que han visto sobre la tierra, y recibirán también algunos vestigios o señales, de lo que va a tener lugar después o en el futuro, como cuando estando en esta vida, recibieron vestigios de las cosas futuras, aunque en un espejo $y$ enigma y conocieron de un modo parcial, lo que ha sido revelado con mayor evidencia y claridad en sus lugares y tiempos. Si alguno fuere limpio de corazón, más puro de mente y de entendimiento más adiestrado, al partir con mayor rapidez, subirá pronto al lugar del aire y llegará al reino de los cielos, como si dijera, a través de las moradas de cada lugar, que los griegos designaron sfairás, esto es esferas, y la Escritura divina llama cielos; en cada uno de los cuales verá en primer lugar lo que alli se lleva a cabo y después conocerá también la razón de por qué se lleva a cabo: y así por orden recorrerá cada lugar, siguiendo al que entró en los cielos, Jesús el Hijo de Dios, que decía: Quiero que donde yo estoy, estén también éstos conmigo. Pero señala también la diversidad de lugares, cuando dice: En la casa de mi Padre hay muchas mansiones.

Cf. P. Ciner, «En la casa de mi Padre hay muchas moradas (Jn 14,2). El camino hacia la Sabiduría en la escatología de Orígenes», en Revista de Teología, Tomo LV, N 127 , Diciembre 2018, 31-48.

47 En griego: $\tau \tilde{\omega} \nu \lambda \circ \gamma\llcorner\kappa \tilde{\omega} v$

48 Prin I, 2, 2 (14-18). Algunos autores denominan «segunda creación» a esta dimensión que está transida de materia física. Cf. por ejemplo, G. Lekkas, Liberté et progres chez Origene (Turnhout: Peeters, 2001).

49 Cf. F. Soler, Acercamientos a la teología del Comer y Beber en el cristianismo antiguo, Communio, 2018, Año 25, N 2, pp. 35-53. 
pación en el Hijo descriptas en el Clo serán las siguientes: la de los perfectos, quienes se unen al Logos-Sabiduría, la de los incipientes que participan en el Logos-carne y en tercer término, la de los filósofos de renombre o las de aquellos que viven de acuerdo al Logos. Los que no participan de alguna de estas tres formas, se alejarán del $\mathrm{Hijo}^{50}$. Este alejamiento no será absoluto, ya que a pesar del olvido, la imagen divina inscrita desde la preexistencia estará siempre presente en ellos y en algún momento de la eternidad volverán a recordarlo. Este recuerdo será justamente el fundamento de la divinización y de la apocatástasis. Por tal razón, este estado de divinización alcanzada por los perfectos, no implicará, el desprecio hacia los menos adelantados en el camino hacia Dios ${ }^{51}$. Vemos, pues, que para el Alejandrino las formas de participación en el Logos descriptas anteriormente, no pueden ser comprendidas como categorías entitativamente diferentes separadas, tal como afirmaba Heracleón. La ubicación en una u otra dependerá del esfuerzo en el ascenso espiritual, de la gracia recibida y del tipo de alimento espiritual que cada alma tenga a su alcance. En ese sentido, creo indispensable mostrar como en el sistema del Alejandrino, la doctrina del libre albedrío y la doctrina de la gracia son absolutamente inseparables ${ }^{52}$.

50 Cf. Clo II, III, 28-31. En estos fragmentos, el alejandrino explica que: «Así, unos participan del Logos mismo que existía en el principio, del Logos con Dios, del Dios Logos: tales eran Oseas, Isaías, Jeremías y todos los que han estado presentes de tal manera que uel Logos del Señor» o «el Logos» ha podido venir hasta ellos. Los segundos son aquellos que sólo saben de Jesús Cristo y él crucificado, y que pensando que el Logos que llegó a ser carne es todo el Logos, sólo conocen a Cristo sólo según la carne: así es la multitud de aquellos que son considerados como creyentes. $Y$ los terceros son los que se han dedicado a las doctrinas que participan de una cierta manera del Logos, como sobrepasando todo el Logos ¿acaso no son los que entre los griegos, siguen las escuelas de filósofos de buen renombre y valor? Los cuartos son personas que en oposición a éstos, creyendo en doctrinas totalmente corruptas e impías, suprimen la providencia que es evidente y perceptible y admiten un fin diferente del bien».

$51 \mathrm{Cf}$. Clo I, VII, 43: «Por esto es imprescindible ser cristiano espiritual y corporalmente a la vez, y donde se deba anunciar el evangelio corporal [literal] declarando no saber nada entre los hombres carnales excepto a Jesús Cristo y éste crucificado, hay que hacerlo. Pero cuando se los encuentre instruidos por el Espíritu, Ilevando en sí los frutos y enamorados de la sabiduría celeste, es necesario hacerlos participar del Logos, que ha vuelto después de haberse encarnado a lo que era en el principio con Dios». CF. también Clo VI, XLIX, 259: «Es necesario todavía hacer esta observación: María, que es superior, va hacia Isabel, que es inferior a ella, [de idéntico modo] el Hijo de Dios va hacia el Bautista: a través de esta enseñanza, sin duda, aprendemos a ayudar a aquellos que están en una condición inferior y más modesta».

52 Esta inseparabilidad se advierte con total claridad en la exégesis que el Alejandrino realiza en el Libro XXXII de Jn 13, que está referida al lavado de los pies y a la última cena. En 
Orígenes es plenamente consciente también, de que el logro de la divinización espiritual será posible tras un arduo combate espiritual, en el que los aspectos temporales deberán ser distinguidos de la dimensión eterna de las criaturas espirituales ${ }^{53}$. El triunfo en esta lucha será el logro de la filiación ${ }^{54}$ adoptiva, por la cual los perfectos lograrán la identificación con ${ }^{55}$. La postulación de la posibilidad de la divinización, recorrerá entonces, la totalidad Cristo mismo ${ }^{56}$. Para Orígenes, por tanto, la verdadera filiación no se dará por naturaleza ${ }^{57}$, sino por adopción del Clo, no habiendo tampoco en este tema rupturas o discontinuidades entre su actividad en Alejandría y en Cesarea. Así en el Libro I, el alejandrino expresará que:

«Entonces los que lleguen a Dios por el Logos, que está con Él, no tendrán más que una sola actividad: comprender a Dios, a fin que todos lleguen a ser perfectamente un hijo, siendo transformados al conocer al Padre, como ahora solo el Hijo conoce al Padre» ${ }^{58}$.

Como muestra de esta continuidad temática, afirmará en el Libro XXXII escrito en Cesarea, lo siguiente:

«Y si es posible ser transformado a partir del estado de servidor de Jesús -ya que los discípulos eran servidores antes de ser hijos pequeños, como se deduce claramente de esto: Vosotros me llamáis «Maestro» y «Señor» y decis bien, pues yo lo soy, y de esto otro: Un siervo no es más grande que su señor, que-, tú examinarás si el siervo llega a ser primero discípulo, luego hijo preceden a la declaración: Hijitos míos, por poco [tiempo] todavía estoy con vosotros pequeño, después hermano de Cristo e hijo de Dios» ${ }^{59}$.

Considero entonces, que en estos fragmentos, se muestra claramente que la posibilidad de la divinización pueda concretarse de

este libro, Orígenes remarcará una y otra, la necesidad de armonizar el progreso espiritual con la gracia divina.

53 En los Libros XX y XXXII del Clo, Orígenes tratará la cuestión de la divinización en todas las etapas del progreso espiritual.

54 J. Ayán Calvo, P. de Navascués y M. Aroztegui Esnaola, Filiación (Madrid: Trotta, 2005).

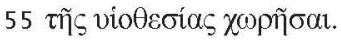

56 Cf. J. Rius Camps, El dinamismo Trinitario en la divinización de los seres racionales según Orígenes, (Roma: Institutum Orientalium Studiorum,1970), pp. 355-473.

57 púøis.

58 Clo I, 92.

59 Clo XXXII, XXX, 374. 
una manera plena, debido a que todos los seres humanos tienen inscripta la huella de la divinidad en sí mismos. Creo también, haber mostrado a través de la comparación de Libros I y XXXII, la coherencia doctrinal del sistema de Orígenes, a lo largo de todos los libros conservados del Clo. En ese sentido, he buscado evidenciar, que si bien se adaptó a los diversos contextos en que le tocó vivir, tanto en Alejandría, como en Cesarea, Orígenes no cambió sustancialmente ni su doctrina teológico-filosófica, ni el modelo pedagógico a través de la cual la transmitió. Quizás, podría deducirse equivocadamente de este análisis, que mi visión de Orígenes es la de un pensador rígido que no fue capaz de cambiar de opinión a lo largo de su vida. Sin embargo, esto no es así. Estoy convencida que, la doctrina del Alejandrino ha tenido el mérito de conciliar un inmenso conocimiento de diferentes líneas teológicas y filosóficas, con la existencia de un núcleo sistemático y preciso que se encuentra a lo largo de esta bella y compleja obra. También estoy convencida que, el Alejandrino a lo largo de toda su vida, distinguió con claridad entre la tradición cristiana y griega. Cuando me refiero a una clara distinción entre tradiciones, estoy sosteniendo que Orígenes, representa el modelo de un teólogo cristiano consciente plenamente de las diferencias entre ambos paradigmas. Dicho de otra forma, y utilizando la hipótesis central del libro de Joseph $\mathrm{O}^{\prime}$ Leary ${ }^{60}$, Orígenes era consciente de las «tensiones» existentes entre ambas tradiciones y con la genialidad que lo caracterizó, no buscó eliminarlas, sino más bien distinguirlas y usarlas cuando hiciera falta iluminar alguna cuestión del texto bíblico. En ese sentido, representa, el modelo de un teólogo cristiano absolutamente comprometido, que no teme reflexionar sobre cuestiones difíciles y que requieren muchas veces confrontar su posición religiosa con ideas filosóficas diferentes a las suyas, respetando el fondo de verdad que fuera posible encontrar en ellas. La fuerza mística de sus obras se nutre en última instancia de su profundo amor por la búsqueda de la Verdad. 


\section{Conclusión}

Sólo a modo de breve reflexión final, quisiera elevar una oración al cielo y agradecer a Dios y al gran Orígenes, por haber tenido la bendición de haber podido realizar la primera traducción al castellano de esta obra. Pido sinceras disculpas, si no fui capaz de poner en palabras toda la inmensa Sabiduría que guarda esta obra, que sin duda, continúa alumbrando nuestras vidas como un faro de luz potentísimo.

\section{Bibliografía}

\section{Fuentes:}

Orígenes, Comentario al Evangelio de Juan/1, Prólogo, F. García Bazán, Introducción, traducción y notas, Patricia, A. Ciner, Biblioteca de Patrística $N^{\circ}$ 115, Madrid: Ciudad Nueva 2020; Orígenes, Comentario al Evangelio de Juan/2, Introducción, traducción y notas, Patricia, A. Ciner, Biblioteca de Patrística N ${ }^{\circ}$ 116, Madrid: Ciudad Nueva, 2020.

Platón, El Banquete, (México: Universidad Autónoma de México, 1947.

\section{Estudios:}

Brown, P., El Mundo en la Antigüedad Tardía, Madrid: Gredos, 1991.

Calvo, J., de Navascués, P. y Aroztegui Esnaola, M., Filiación, Madrid: Trotta, 2005.

Blosser, B., Become like the angels. Origen's Doctrine of the Soul, Washington: Catholic University of America Press, 2012.

Brown, P., El Mundo en la Antigüedad Tardia, Madrid: Gredos, 1991.

Caamaño, J. C., Giudice, H., (eds.), Patrística, Biblia y Teología. Caminos de diálogo, Buenos Aires: Agape, 2017.

Castagno, A., (director), Diccionario de Orígenes, Burgos: Monte Carmelo, 2003. 
Ciner, P. Plotino y Orígenes. El Amor y la Unión Mística, Mendoza:

Ed. Del Instituto de Filosofía, 2000.

Ciner, «Presencia de la Teología del Corazón en el pensamiento de Orígenes», en Estudios Patrísticos, Ediciones del IAPCH (2004), 21-44.

Ciner, P., «Una relectura del De Principiis a la luz del Comentario al Evangelio de Juan. La cuestión de la preexistencia», en Teología y Vida, LV (2014), 263-285.

Ciner, P., Implicancias Teológicas y Místicas de la noción de Sabiduría en Orígenes Publicación del Centro de Estudios de Filosofía y Letras (2010), $\mathrm{N}^{\mathrm{o}} 6$.

Crouzel, H., Origen et Plotin. Comparaisons doctrinales, Paris: Pierre Téqui, 1991.

Crouzel, H. Orígenes. Un teólogo controvertido, Madrid: BAC, 1999.

García Bazán, F., La Biblioteca gnóstica de Nag Hammadi y los orígenes cristianos, Buenos Aires: El Hilo de Ariadna, 2013.

Hadot, P., Ejercicios espirituales y filosofia antigua Madrid: Siruela, 2006

Heine, R., Origen Scholarship in the Service of the Church, New York: Oxford University Press, 2010.

Luttikhuizen, P., La pluriformidad del cristianismo primitivo, Córdoba: El Almendro, 2002.

O'Leary, J., Christianisme et philosophie chez Origène, Paris: Cerf, 2011. Orbe, A., La Epinoia. Algunos preliminares históricos de la distinción кat'ż́ívolav (En torno a la Filosofía de Leoncio Bizantino, Roame: Pontificia Universitas Gregoriana, 1955.

Rius Camps, J., El dinamismo Trinitario en la divinización de los seres racionales según Orígenes, Roma: Institutum Orientalium Studiorum, 1970.

Rius Camps, J., «Comunicabilidad de la Naturaleza de Dios según Orígenes» Roma: Orientalia Christiana Periodica, 1968.

Wolinski, «Le recours aus énivotaı du Christ dans le Commentaire sur Jean d' Origene», en Origeniana Sexta, en G. Dorival/ A. Le Boullec (eds.), Peeters, (1995),466-492. 
